\title{
Comparative Analysis of the Effect of Direct and Indirect Taxation Revenue on Economic Growth of Nigeria
}

\author{
Etim Osim Etim ${ }^{1}$, Nsima Johnson Umoffong ${ }^{2}$, Austin Uchechukwu Nweze ${ }^{3}$, Samuel Sunday Charlie ${ }^{4}$, Anselem \\ Monday Udoette ${ }^{5}$
}

1,2,4,5 Department of Accounting, Faculty of Business Administration, University of Uyo, Nigeria

${ }^{3}$ Professor Department of Accounting Faculty of Management Sciences Enugu State University of Science and Technology Enugu, Nigeria

\begin{abstract}
The study was conducted to comparatively analyse the effects of direct and indirect taxation revenue on economic growth of Nigeria. This was necessitated by the revenue shortfall from Crude oil sales which has been the main revenue earner of the government and the latent potentials of taxation as the most reliable source of revenue. The study was designed to find out which of the tax category affect economic growth most in Nigeria. Ex post facto research design was the research design involving secondary data extracted from the Central Bank of Nigeria (CBN) and Federal Inland Revenue Service (FIRS) published reports. Data were analyzed using descriptive and inferential statically techniques using correlational and regressional statistics. Results reveal that direct taxation has more negative effect on the economy than indirect taxation as evidenced by the adjusted $\mathrm{R}^{2}(\mathrm{Direct}$ taxes 80\%; Indirect taxes 67\%, case wise predictive residuals (maximum values: direct taxes 6.123, indirect taxes 5.893). It was therefore recommended that the government should review regulatory and operational guidelines at the oil and gas sector and tax reforms in the form of reliefs and other incentives to companies to encourage investors and boost productive activities to enhance economic growth of the country.
\end{abstract}

KEYWORDS: Direct Taxation, Indirect Taxation, Economic Growth, Tax Reliefs, Tax Incentives

\subsection{INTRODUCTION}

The relevance of taxation as an instrument for economic growth and development is recognized globally in both develop, developing and underdeveloped economies. From ancient time, public finance is majorly funded through taxes imposed on individuals, corporation and other taxable institutions by the government through constituted authorities or institutions saddled with the traditional function of tax administration.

In Nigeria as elsewhere, taxation is a principal component of government fiscal policy measures, designed to stabilize the economy, create employment opportunities, and stabilize price levels and balances of payment and trade, grant incentives to the industrial and manufacturing sector and boosting productive capacity while encouraging investments in different and most preferred sectors of the economy (Etim, Umoffong and Confidence, 2020).

The history of economic thoughts of both developed and emerging markets, reveals that taxation is an important instrument at government disposal for socio-economic planning; not only to generate revenue, but also to create fiscal objectives that influences the direction of growth and development. The direction and effect of the relationship as remained debatable and unresolved controversy in accounting, taxation, economics and finance. But at least there seem an agreement among researchers that some measures of influence exist between taxation revenue and economic growth in all types of economy.

In general perspective, government can derive revenue from tax and non-tax sources, oil and non oil, internally and externally generated, among other sources or classification. However, whatever the source or classification taxation revenue are the most potent, reliable and efficient source of revenue to both developed and developing economies if properly administered and managed (Konrad, 2014; Etim, Umoffong and Ekanem, 2020).

Taxation revenue permits the financing of government activities with the potentials effects upon the rate of growth and/or development in relation to the level of governmental expenditure, on resources allocation, provision of social infrastructure and also on distribution of income and wealth. Taxation also alters the determinants of economic development through capital formation, technological change, and factor supplies.

A critical review of the effects of taxation on economic growth can be most usefully examined through an argument from the diverse channels through which tax policy can affect the economy. This reasoning follows the fact that, 
in practice, taxation effect are measured from direct and indirect taxations point of view. For instance, company income tax, a form of direct taxation is statutorily imposed on an incorporated business, the incidence and burden of the tax is generally seen to be distributed in the entire economy among participants in the production and consumption value chain (Etim, Mbobo, Confidence and Ekanem, 2020). At the one end, the key relationship is that the burden of company income tax is shared between the returns to capital in form of investor's profits and the return to Labour in the form of wages paid to employees. If there is a "reduction in company income tax" rates, in the form of incentive, companies would accumulate capital, attract inward investment of capital, and incentivise innovation "(Engen and Skinner, 2008), thereby expanding output. At the other end, increased company tax rates is detrimental to investment expansion and distortive to productivity and reducing gross domestic product per capital. The reverse of the above scenario holds for indirect taxation such as Value added Tax (VAT).

Also, taxation as a fiscal policy instrument is a tool for societal development by those entrusted with the social contract to collect taxes and apply same for the delivery of security and public goods that enhance the citizenry wellbeing. The treatise of taxation and fiscal activities of government is premised on the logic that taxation and government spending lead to higher growth rate. As argued by Dalibor (2002), "government redistribution of revenue can stimulate savings and investments by redistributing wealth to individuals with a higher marginal propensity to save (MPS)". In a general perspective, 'higher marginal propensity to save can be found among people with higher incomes and redistribution from the rich to poor or from the poor to the rich thus boosting output and other economic activities from various sectors of any economy. There is, therefore, the need to empirically compare the effect of direct and indirect taxation on economic growth to support theoretically view in the case of Nigeria.

\subsection{Statement of the Problem}

Nigeria is today faced with the challenge of optimizing her revenue profile which has been predominantly from Oil; whose prices are externally driven and outside the control of the government. This resulting in recent years to revenue or budget deficits prompting extensive borrowings with it attendant's debt overhung effects. This has been the case for about the past four decades where the government has not pay particular attention to taxation as a potent and more reliable revenue source ranking Nigeria very low among nations in terms of taxation revenue buoyancy. Consequently, the ratio of taxation revenue to Gross Domestic Product (GDP), a common basis of economic growth for Nigeria as ranged between 2.9 and 4.8 per cent since 2009 to date compared to countries such as Indonesia and Malaysia with between 13.35 and 15.3 per cent respectively within the same period (Etim, Umoffong and
Ekanem, 2020). This describe a weak tax revenue profile that might have to be fortified if the country must reverse the abysmal trend.

From another point of view, several empirical investigation has been carried out to examine the effect of taxation on economic performance particularly using GDP Studies available in extant literature are lacking in comparative terms between direct and indirect taxation. Most of the studies examine the effect disaggregatively without studying the effect distinctively from direct and indirect revenue perspective.

Furthermore, it has always been incorrectly assumed that fiscal policy framework and their empirical outcomes are equally applicable for all economies whereas there exists considerable multifariousness in economic structures among all nations. This study is designed to examine the effect of taxation revenue on economic growth in Nigeria from the direct and indirect taxation revenue perspective for the period 1980 to 2019.

\subsection{Objective of the Study}

The fundamental objective of this study is to comparatively analyze the effect of direct and indirect taxation revenue on economic growth of Nigeria from 1980 to 2019. Other specific objectives include the following:

i. To examine the effect of direct taxation revenue on economic growth of Nigeria for the study period

ii. To analyse the effect of indirect taxation revenue on economic growth of Nigeria for the study period

iii. To evaluate the comparative effect of direct and indirect taxation revenue on economic growth of Nigeria for the study period.

\subsection{Research Question}

The research questions raise for the investigation are as follows:

i. Does direct taxation revenue has any significant effect on economic growth of Nigeria between 1980 and 2019 ?

ii. Is there any significant effect of indirect taxation revenue on economic growth of Nigeria for the period of study?

iii. What is the pattern of comparative effects of direct and indirect taxation revenue on economic growth of Nigeria for the period of study?

\subsection{Research Hypotheses}

The following hypotheses are formulated for the study in null form.

$\mathrm{Ho}_{1}$ : there is no significant effect of direct taxation revenue on economic growth in Nigeria.

$\mathrm{Ho}_{2}$ : Indirect taxation revenue has no significant effect on economic growth of Nigeria between 1980 and 2019. 
$\mathrm{Ho}_{3}$ : Comparatively, Direct and indirect taxation revenue has no significant combine effect on economic growth of Nigeria between 1980 and 2019.

\subsection{Significance of the Study}

This study is designed with a view to expanding the knowledge frontier on the effect of taxation on economic growth of Nigeria. Empirical studies are medium by which societal challenges are addressed and solutions proffered to socio-economic problems. This study addresses a contemporary issue in both the academia and societal cycles. The findings of the study would therefore be of relevance to different categories of stake-holders.

To the government, the findings will shed light on the efficiency of taxation as a potent fiscal policy instrument and the need to fine-tuning the tax policies in the country.

To the taxable persons, the finding would sensitize on the importance of tax compliance and regularity of tax obligation fulfilment by all. Tax consultants and practitioners and those involved in business advisory services, the findings would serve as reference material in key areas to explore to mitigate issues of multiple taxations and other areas as they would affect both the government and tax payers.

Conclusively, this research will be profitable to academicians, scholars and students as well as lecturers in accounting and other allied disciplines as this work may aid them to acquire in-depth understanding on taxation revenue as it affect economic growth and related issues round the world in their future researches and studies. The study also provides supplementary literature that will shoot out specific and contemporary issues and theories on taxation and economic growth.

\subsection{REVIEW OF RELATED LITERATURE}

The review of related literature for the study is examined in three sub-sections covering the conceptual review, theoretical review and the review of empirical studies and the gap in the literature.

\subsection{Conceptual Framework}

The key concept and variables of the investigation are explained in this section of the chapter. This will address the major issues of the study.

\subsubsection{Economic Growth}

Economic growth has long been considered an important goal of economic policy with a substantial body of research dedicated to explaining how this goal can be achieved at both the short and long-run (Fadare, 2010). The concept has received much attention among scholars and political commendators. According to Khorravi and Karimi (2010), classified studies estimate that economic growth is largely linked to expenditure of government, which is a function of revenue generated and available for use by the government.

A country's economic growth is determined using the per capita income (PCI), which is obtained by the division of Gross Domestic Product (GDP) by the population at a point in time. It represents the expansion of a Country's potential GDP or output. Economic growth models that incorporate public sector services assert that the optimal tax policy lingers on the nature and characteristics of services provided. That is, if the government spent substantially on infrastructures, this will trigger growth (Olapade and Olapade, 2010; Etim, et al., 2020). Economic growth has provided insight into why a state grows at different rates over time; and this influences government in her choice of tax rates and expenditure levels. Fiscal policy for which taxation is a potent variable is generally assumed to be correlated with economic growth, or more precisely, when appropriate fiscal measures are implemented, they are used to stimulate economic growth (Khorravi and Koarimi, 2010; Etim, et al., 2020).

Conceptually, therefore, economic growth is the steady process of increasing the national income or output through government's sensible effort of leveraging economic variables through fiscal policy or monetary policy measures. From the Keynesian analysis, it is emphasized that demand management policies can and should be applied to improve macroeconomic performance. The logic is that the private sector is inherently unstable and subject to frequent and quantitatively important disturbances in the components of aggregate demands. It is the task of counter cyclical or stabilization policies to offset these private sector disturbance and so keep real output close to its market equilibrium time path (Omitogun and Ayinola, 2007).

According to Dwivedi (2004), economic growth is a sustained increase in per capital national output or net national products over a long period. It implies that the rate of increase in total output must be greater than the population growth rate. Another quantification of economic growth is that national output should be composed of such goods and services which satisfy the maximum want of the maximum number of people.

Economic growth can be determined by four important indices namely: Human resources, Natural resources, Capital formation and Technological development (Etim, 2015). In all instances, economic growth is measured and proxy by Gross Domestic Product (GDP) or Real Gross Domestic Product (RGDP).

\subsubsection{Objectives of Taxation}

In the conventional Accounting, Economics and Finance literature, the objectives or purposes of taxation have been enumerated and extensively discussed to include: to generate revenue for the government, to control the economy as economic stabilizes, to redistribute income between the wealth and less wealthy citizens, to discourage the consumption of certain goods, protect domestic industries, to stimulate domestic industries, to stimulate domestic production, and creation of employment, and to correct balance payment imbalances (Abiola and Asiweh, 2012; 
Ifurueze and Ekezie, 2014; Bruno and Emmanuel, 2019; Etim, et al., 2020).

Nzotta (2007) noted that taxes objectively have three purposes, namely: allocative, distributional and stabilization. The allocative function of taxes subsume the determination of the pattern of production, the goods that should be produced, who produce the goods, the relationship between the private and public sectors and the point of social balance between the two sectors. The distribution of taxes identify with the form in which effective demand over economic goods is shared, among the populace in the society.

The distributive function is concerned with the distribution of income and wealth to ensure conformity with what society considers a fair or just or equitable state of distribution. The stabilization function of taxes "seeks to attain high level of employment, a reasonable level of price stability, an appropriate rate of economic growth, with allowances for effect on trade and on the balance of payments". Musgrave and Musgrave, (2004); Nwezeaku (2015) argues that "the scope of these functions depends, inter alia, on the political and economic orientation of the people, their needs and aspirations as well as their willingness to pay tax". This implication is that, the extent to which any government can perform the functions depend largely on the ability to design tax plans and administration, and the willingness and patriotism of the governed.

\subsubsection{Structure of Nigerian System}

The structure of the Nigerian tax system has passed through significant changes in recent times. However, the tax structure is designed in a manner as to contribute to economic growth via revenue generation to the government to finance her expenditure. On the framework or basis of incidence, taxes are structured into direct and indirect. There are different components of direct taxation in Nigeria. These include, the personal income tax (PIT), Petroleum Profit tax (PPT), Companies Income tax (CIT), Education tax (ET). The Personal Income Tax is currently being regulated under the Personal Income Tax Act 2004, an amended in 2011. The Petroleum Profit Tax (PPT) is regulated by the provisions of the Petroleum Profit Tax Act (PPTA) of 1990 as amended in 2004. PPT is charged on the profits of a company engaged in Petroleum sector upstream. Companies in Nigeria incorporated as such are taxed under the Companies Income Tax Act introduced in 1961 and amended up to 2007. Education Tax in Nigeria is under the regulation of the provisions of the Education Tax Act No.7 promulgated in 1993. The tax is payable by all companies at the rate of two (2) per cent of the assessable profit defined in the Company Income Tax Act. The assessment of education tax and company income tax are carried out concurrently.

The different prominent components of indirect taxation in Nigeria include, Value Added Tax (VAT) and Custom and Excise Duties (CED). VAT is regulated by the Value Added Tax Act (VATA) of 2007, as amended to date.
The VAT assessment in Nigeria is destination based, implying that the tax is levied on goods and services consumed within the tax jurisdiction. Until February 2020, VAT was changed at $5 \%$, but increased to $7.5 \%$ by the Federal Government of Nigeria. The administration of PPT, CIT, and VAT is vested on the Federal Inland Revenue Services (FIRS). The Custom and Excise Duties (CED) is regulated by the provisions of the Custom and Excise management Act of 1990. The duty is chargeable on all goods and services imported and Exported into and out of the country. The tax is administered by the Nigerian Custom Services and is also referred to as import and export duties. Currently, the duties are chargeable within the range of 2.5 per cent to 100 per cent depending on the product.

\subsubsection{Direct taxation and Economic Growth}

Nigeria has a portfolio of taxes classified under direct taxes, and include petroleum profit tax, company income tax and personal income tax. These taxes have effect on the economic growth of Nigeria. Eric and Johnathan (1996), Etim, et al., 2020) identified five ways direct taxes affect economic growth of Nigeria. Firstly, high tax rate can discourage the investment rate (capital stock growth rate) through high statutory tax rates on company and incomes, high effective capital gain tax and low depreciation or capital allowance. Secondly, high taxes reduce labour supply growth by discouraging labour force participation or distort occupational choices and also affect the choice of skills acquisition, education, and training. Thirdly, tax policy reduces productivity growth by discouraging Research and Development (R \& D) and development of venture capital for hi-tech industries activities whose spillover effects can potentially enhance the productivity of existing labour and capital. Fourthly, tax policy influences marginal productivity of capital by distorting investment from heavily tasked sectors into more lightly taxed sectors with lower overall productivity. Fifthly, high taxation on labour supply can distort the efficient use of human capital by discouraging workers from employment in sector with high social productivity but a heavy tax burden. There is fundamentally two views about the prime motivation for savings. Firstly, the relationship between income and consumption, under this view, it is believed that higher tax burden will likely reduce savings mainly by having lowered after tax current income which affects linear relationship between savings and investments. Saving is seen as mainly resulting from a choice between present and future consumption. A high direct tax reduces savings, investments and may slow down economic growth, though it increase government investment which might have no minimal effect on economic growth.

\subsubsection{Indirect Taxation and Economic Growth}

The main indirect taxes in Nigeria are Value Added Tax (VAT) and Custom and Excise Duties (CED). High indirect tax discourages consumption, and are characterisized by flat rate and often regressive (Anichebe, 2013). The effect 
of indirect tax on economic performance is fairly limited and neutral with regards to savings and investment. It is the belief of most economists that economic efficiency can be achieved with a relatively low level of direct taxation and high level of indirect tax.

Conceptually, this framework is diagrammatically shown as follows:

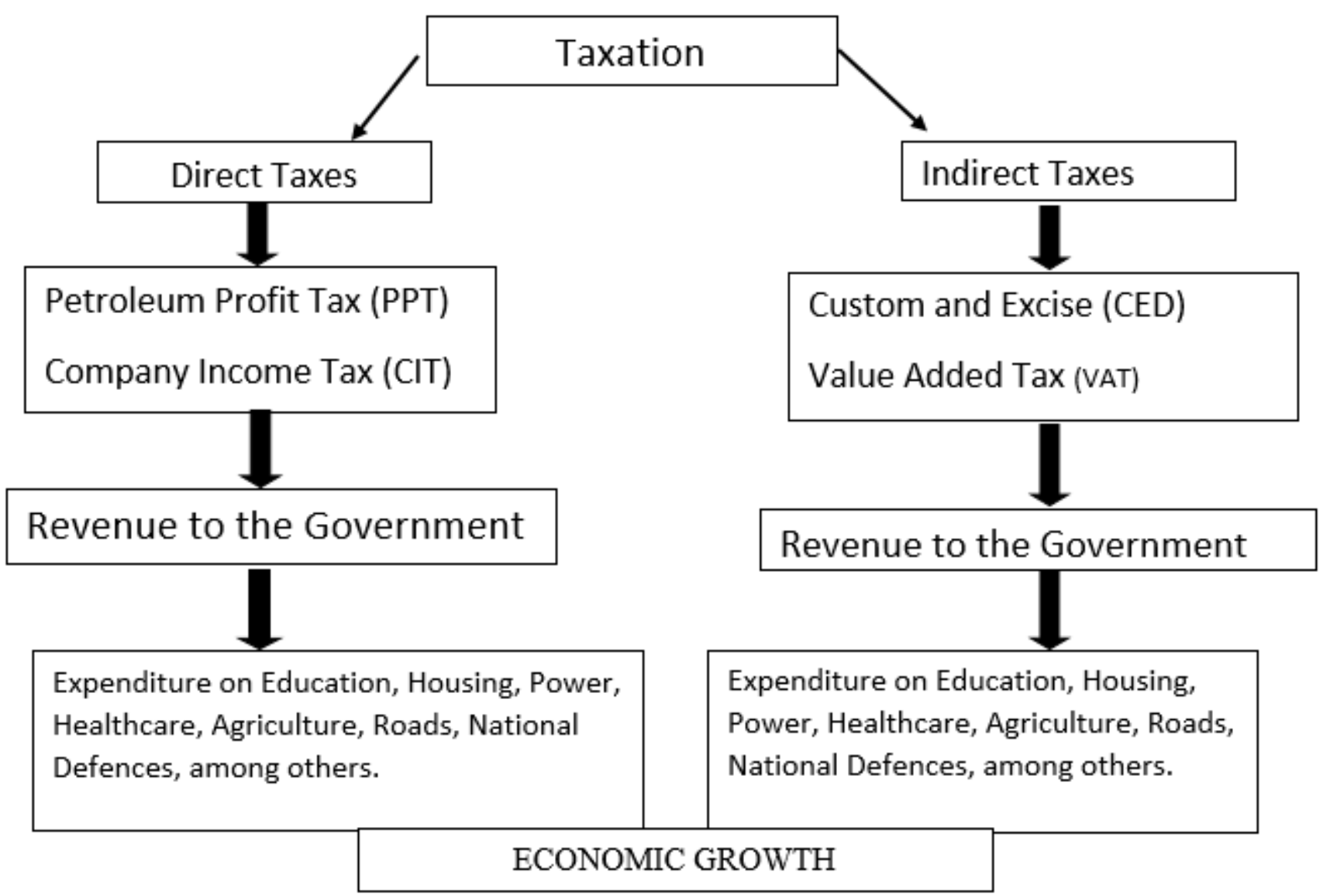

Figure I. Conceptual Framework of the Study

Source: Researcher's Concept (2020)

The flowchart depicts the flow of direct and indirect taxation revenue in to the government treasury for use in meeting both recurrent and capital expenditure commitments of the government.

\subsection{Theoretical Framework of the Study}

Tax revenue is expected to contribute to the growth of the economy as opined in the growth theories. For this study, one taxation and economic growth theory each are explained as the foundation upon which the research anchors.

\subsection{Solow Growth Theory.}

Solow (1956) developed a growth model called Solow model which explains that the long-run rate of growth in any economy is exogenously influenced by the rate of technical progress. Other neoclassical economists further expanded the theory such as Domar (1957) who establishes the Harrod-Domar model which include the savings rate in an economy as one of the long-run growth rate variable. Thus, the neoclassical economists are instrumental in the development of the growth model.
A modification of the neoclassical growth theory included endogenous factors into the model such as human capital, innovations, knowledge and positive externalities. The model holds that policy measures within an economy, such as taxation revenue positively influence the long-run growth rate in an economy in the form of increase in real GDP. Taxation revenue is thus a dominant factor in country's growth rate, which makes the model relevant to the study at hand.

\subsubsection{Socio-political Theory}

This theory of taxation was developed by Adolph Wagner (Bhartia, 2009). The theory states that social and political objectives should be the major factors in selecting taxes and determining tax rates. He advocated that a tax system should not be designed to serve individuals, but should be used to cure the ills of the society as a whole. Wagner did not believe in individualist approach to a problem. He stated that each economic problem be looked at in its Social and Political context and an appropriate solution found thereof. Consequently, a tax structure should not be 
designed to serve individual members of the society, but should be used for the benefit of all as the ills of the society is curved. This theory reflects and relates to a normal development process and a bench mark for comparison of a country's specific empirical evidence over time. Thus, it relevance to this study.

\subsection{Empirical Studies Review}

Several studies in the area of taxation and economic growth exists in the literature both for developed and developing countries including Nigeria. Some of these empirical investigations are reviewed here with.

Adereti et al. (2011) conducted empirical studies on impact of Value Added Tax (VAT) on economic growth in Nigeria using data spanning the period 1981 to 2007. Gross Domestic Product (GDP) was used as a proxy for economic growth, applying the Ordinary Least Squares (OLS) regression analysis technique. The results show positive and significant relationship between the VAT tax revenue component and economic growth in Nigeria. The main shortcoming of the study was the use of only one tax revenue head without carrying out a comparative analysis to find out which type of tax might have driven GDP most during the period of study.

Okafor (2012) studied the impact of income tax revenue using a set of federal government income tax revenue heads between 1994 and 2008 on Nigeria's economic growth proxy by Gross Domestic Product. He applied the Ordinary Least Square (OLS) analytical technique. The outcome of the analyses showed a positive and statistically significant relationship between the variables studied.

In a study by Onaolapo et al. (2013) on the impact of Value added Tax on revenue generation in Nigeria using Secondary date obtained from the Central Bank of Nigeria (CBN) and Federal Inland Revenue Services (FIRS) annual reports and statements. The researchers adopted a stepwise regression analysis method and data analysis technique with results showing that Value Added Tax has statistical and positive significant effect on revenue generation in Nigeria.

Ifurueze and Ekezie (2014) studied the Nigeria tax system and economic growth: A time series analysis using time series data covering the period 1994 to 2012 obtained from CBN statistical bulletin and Federal Inland Revenue services (FIRS) annual reports various edition. Regression analysis was used to examine the relationships between the variables of study. The result of the analyses shows that the variables were positively correlated.

Afuberoh and Okoye (2014) investigated the impact of taxation on revenue generation in Nigeria: A study of Federal Capital Territory and selected states using mixed research method combining primary and secondary research designs to gather data for the study. They applied regression analysis in the study using SPSS version 17.0. Result shows taxation has a significant contribution to revenue generation and gross domestic product in the country over the period of their study.

Abata (2014) examined the impact of tax revenue on Nigerian economy (case of Federal Board of Inland Revenue). The researcher adopted survey research design method using questionnaire administered to 100 staff of the Federal Board of Inland Revenue (FBIR). Data gathered were analyzed using chi-square statistical method. Result show that tax revenue significantly affected the revenue generation in Nigeria and budget implementation in the country. The research method adopted for this study was deem inappropriate as sample selected for the study do not represent a good proportion of the population, among other issues such as budget implementation which was not a variable of investigation in the study but suddenly brought into the discussion and findings.

Chibu and Njoku (2015) investigated the impact of taxation on the Nigerian economy from 1994 to 2012 using secondary data obtained from Federal Inland Revenue Services (FIRS) and National Bureau of Statistics (NBS). The variables studied were subjected to Unit Root test, which revealed that the variables were stationary. The Cointegrated test reveals a Long-run relationship among variables of study. The result of the statistical analyses involving ordinary least squares (OLS) shows that positive relationship existed between tax revenue items and gross domestic product in the country.

Abomaye-Nimenibo et al. (2018) conducted a study on an empirical analysis of tax revenue and economic growth in Nigeria from 1980 to 2015. Data for the study were secondary time series data obtained from the CBN, NBS an FIRS reports, and analyzed using multiple regression analysis. Result discloses a positive and statistical significant relationship among the variables studied. They recommended robust tax administration machinery in order to boost revenue generation and in turn economic growth of the country.

Dang and Bala (2018) studied the contribution of tax revenue for national development in Nigeria. The study looks at how the various major sources of tax revenue such as Petroleum Profit Tax (PPT), Companies Income Tax (CIT), Custom and Excise Duties (CED) and Value Added Tax (VAT) affect Real Gross Domestic Product (RGDP). Time series data for the period 1981 to 2013 was used and analyzed. Using Error Correction Model (ECM), Augmented Dickey Fuller unit root test, and Johansen, Co-integration test. The study findings show that tax revenue has little contribution to national development in Nigeria, with some taxes having negative relationship with RDGP. They concluded by advocating for stringent financial controls to minimize revenue leakages in the system.

Udofot and Etim (2017) investigated the relationship between tax revenue components from SMEs and economic growth in Nigeria from 1980 to2015. Data for the study were obtained from the Central Band of Nigeria 
$(\mathrm{CBN})$ statistical reports and Federal Inland Revenue Services (FIRS) annual reports various editions. Data gathered were analysed using regression and correlation analyses. The results show that the variables correlate positively and significantly and recommended overhauling of the entire tax administration machinery to enhance more revenue generation.

Bruno and Emmanuel (2019) examines tax revenue and the Nigeria economy from 2000 to 2017 using secondary data sourced from the Central Bank of Nigeria statistical bulletin various editions. They adopt ex-post facto research design. Ordinary Least Squares (OLS) regression technique to analyse the data gathered. Their findings revealed that there exists insignificant effect of tax revenue on economic growth during their period of investigation.

Lyndon and Paymaster (2016) conducted an investigation on the impact of Companies' Income Tax, Value Added Tax on economic growth of Nigeria from 2005 to 2014. They adopted ex-post facto research design and made use of time series data for ten years; using multiple regression analysis technique. Result revealed both Company Income Tax and Value Added Tax had positive and significant impact on economic growth in the period of the study. In the study, no distinction was made between direct and indirect taxation effect on the economy which is the main objective of the current study.

Etim et al. ( 2020 ) also carried out study to empirically analyse the relationship between tax revenue components and economic growth in Nigeria. The analytical tools used were unit root test, Co-integration test, error correction mechanism and Ordinary Least Squares (OLS). The variables for their study were economic growth for dependent variable, Petroleum Profit tax, Companies Income Tax, Personal Income Tax and Value Added Tax as independent variables. Results show CIT, PIT and VAT as poor economic growth indicators, while PPT was the only propeller of economic growth.

In another study titled "Does taxation drive economic development in Nigeria?", Etim et al., (2020) examined whether taxation revenue drive economic development proxy by human development index of the country, using data spanning from 1985 to 2018 obtained from the Central Bank of Nigeria (CBN) statistical bulletin, Federal Inland Revenue Services (FIRS) tax report and human development index report by United Nations Development Programme (UNDP). Data collected were analyzed using descriptive and inferential statistics involving multiple regression technique. Findings reveal an inverse and statistically significant relationship between CIT and human development index (HDI), direct and significant relationship between VAT and HDI and insignificant relationship between PIT, PPT, and HDI. This implies mixed results between the variables of the investigation.

In a similar study titled "Does taxation propel economic growth in Nigeria?," Etim et al., (2020), investigated the effect of taxation on economic of Nigeria using Per Capita Income (PCI) as dependent variable and PPT, CIT, VAT, and PIT as independent variables. Data were obtained from CBN statistic bulletins, Federal Inland Revenue Services (FIRS) and Socio-Economic Statistics report by National Bureau of Statistics (NBS). The analysis adopted multiple regression technique. Result reveals inverse and significant relationship between company income tax and per capita income (PCI), while PIT, VAT and PPT disclosed positive and significant relationship. The results, therefore, left the question with no definite 'Yes' or 'No' answer as to whether taxation propel economic growth in Nigeria following the mixed results.

Taxation and manufacturing sector Output in Nigeria was examined (Etim, et al., 2020) using manufacturing sector output as the dependent variable and PPT, CIT, VAT and PIT as independent variables from 1985 to 2018. Data were analysed using ordinary least square technique with results disclosing that CIT and CAT not statistically significant but positively correlated with manufacturing sector output, while PPT and PIT were statistically significant and positive in relation to manufacturing sector output. The findings affirm the theoretical conception that CIT discourages entrepreneurship.

\subsection{Summary of Empirical Review and Gap in the Literature}

From the above reviewed empirical literature, prior studies did not consider aggregating the total revenue components into direct and indirect types in order to assess and confirm the assertion that direct taxes discourage entrepreneurship and investment while indirect taxation does. This is considered in this study. Also, most of the studies made use of gross national product instead of real gross domestic product which reflects actual economic reality. This study makes use of the real gross domestic product.

In another dimension, the predictive power of regression models lies on extent of data range which must be relatively long for a good estimation and forecast. Some of the earlier studies did not consider the fundamental feature of good model estimation by making use of time series data that cover a lesser time range of thirty years (30) data size or more. This study is considering a forty years (40) time frame, and hence a more robust result is expected than those from earlier studies.

\subsection{METHODOLOGY}

This Section is devoted to discussing the research methods applied and adopted for the study. The issues discussed include the research design, population of the study, Sample size and sampling technique, nature and sources of data, method of data collection, theoretical specification of model, empirical specification of model and description of variables. Others are method of data analysis and the decision oration of study. 


\section{1}

\section{Research Design}

This research concerns the adoption of ex-post facto research design.

It is a secondary data research making use of time series data and is carried out after the proceedings have taken place and data are before now in existence. The design is considered appropriate for this study giving the fact that this study is carried out after the events had taken place and facts cannot be manipulated for the purpose of explaining and interpreting existing phenomenon and conditions. More so, the research design permits explanation of the relationship between two or more variables and substantiating hypotheses testing and answering the research questions of the research.

\subsection{Population of the Study}

The population of this research covers all categories of taxes collectible in Nigeria and economic growth indices or variables, that is, all indices used in measuring economic growth in the country.

\subsection{Sample size and Sampling Technique}

This study being a comparative investigation comparing two classes of taxes direct and indirect taxation revenue, the researcher adopts purposive sampling technique to select two kinds of taxes each under each category. For direct taxation revenue, Petroleum Profit Tax (PPT) and Companies Income Tax (CIT) while for indirect taxation revenue, Value Added Tax (VAT) and Customs and Excise Duties (CED) are selected. Also one of the yard-stick used in selecting the taxation revenues is the fact these are the commonest taxes with documented evidences for ease of reference and collection of data from official records or databases.

\subsection{Nature and Sources of Data}

The data for the use in the study is secondary data obtained from official databases of the Central Bank of Nigeria (CBN) statistical bulletins and Federal Inland Revenue Services (FIRS) for the period 1980-2019; forty (40) years time frame. Thus, time series data is the main data used for the study. The data collected are subjected to preestimation tests, estimation tests and post-estimation tests using relevant statistical software package.

\subsection{Theoretical Specification of model}

The theoretical specification of model is derived from the conceptual framework of the study and presented in Figure 3.1 that follows.

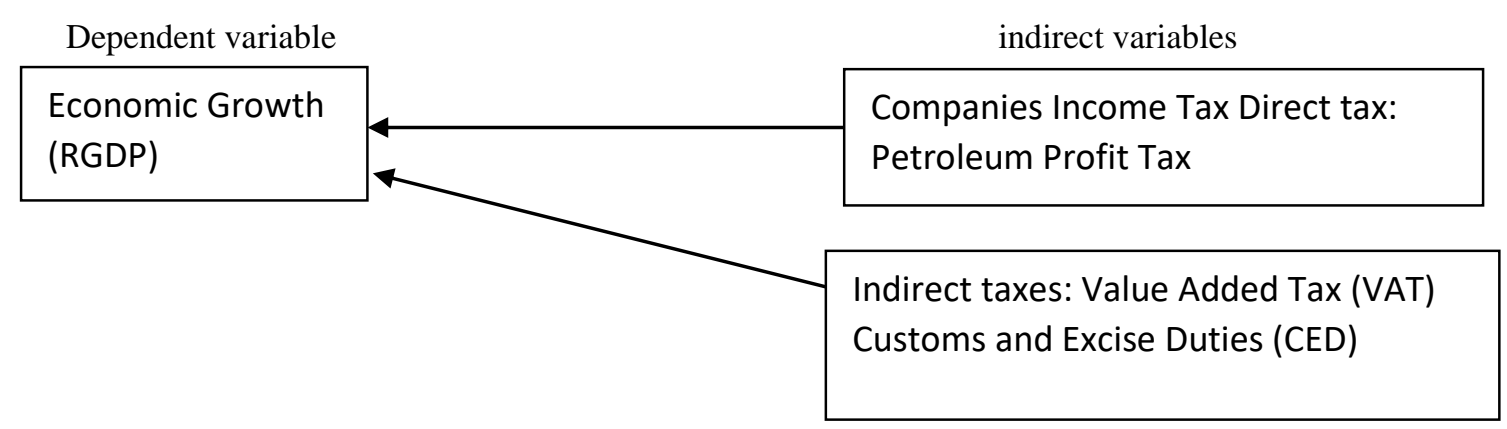

Figure 3.1: Theoretical Model of the Study

Source: Researcher's Concept (2020).

\subsection{Empirical Specification of the Model}

The empirical specification is built on the neoclassical growth framework and reflects the theoretical framework of this study using the following variables.

Economic Growth- Real Gross Domestic Product (RGDP)

DT- Direct taxes: Petroleum Profit Tax (PPT) and Companies Income Tax (CIT)

IT- Indirect taxes: Value Added Tax (VAT) and Customs and Excise Duties (CED)

The specific empirical model is thus formulated as:

RGDP $=a_{0}+$ Direct taxes $+\mu$----------- model 3.1 $a_{a}$

Further expanded as:

$\mathrm{RGDP}=\mathrm{a}_{\mathrm{o}}+\mathrm{PPT}+\mathrm{CIT}+\mu--------$ model 3.1

The model in its logarithm form is presented as:

$\log \mathrm{RGDP}=\mathrm{a}_{\mathrm{o}}+\log \mathrm{a}_{1} \mathrm{PPT}+\log \mathrm{a}_{2} \mathrm{CIT}+\mu$-----model 3.1

\begin{abstract}
RGDP $=b_{o}+$ indirect taxes + e --------- model 3.2a Further expanded as: RGDP $=b_{0}+$ VAT +CED +e ---------model 3.2
\end{abstract}

The model in its logarithm form is shown as:

$\log \mathrm{RGDP}=\mathrm{b}_{\mathrm{o}}+\log \mathrm{b}_{1} \mathrm{VAT}+\log _{2} \mathrm{CED}+\mathrm{e}$ model 3.2c

In the composite form, the overall model in logarithm form is stated as:

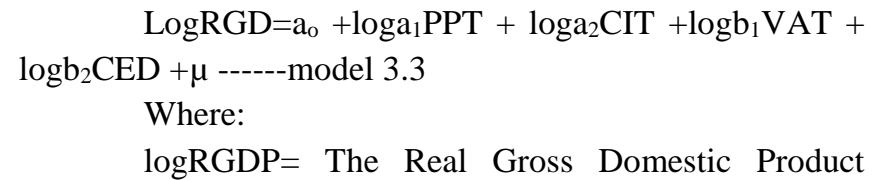
values for the period of study $a_{o}, b_{o}=$ Constant

$a_{1}, a_{2}, b_{1}, b_{2}=$ Coefficients of the explanatory or independent variables

$\mu, \mathrm{e}=$ Stochastic error term

Model 3.1 is for test of hypothesis one, model 3.2 for hypothesis two and model 3.3 for test of hypothesis three. 


\subsection{Description of Variables and A priori Expectation}

The variables in our model are described in

this section of the research.

Dependent Variable:

Real Gross Domestic Product (RGDP): This is the dependent variable in the models. It is the total monetary value of all finished goods and services produced within a country's boarder in a specified fiscal year, on a year by year basis from 1980 to 2019 .

Independent Variables:

a priori Expectation Petroleum Profit Tax (PPT):

Taxes charged on companies

Operating at the downstream sector of the oil and

gas industry in Nigeria. A form of direct taxation on income:

Companies Income Tax (CIT): A form of direct tax charged

On incorporated companies registered with the corporate affairs

Commission (CAC)

Value Added Tax (VAT): A form of indirect tax charged on $+$

Goods and services chargeable to VAT and paid by both individuals

and corporations.

Custom and Excise Duties (CED): These are a form of indirect

Taxes payable by importers and exporters on specified goods imported or exported into or out of the country as well as those

imposed on the goods produced locally.

The main assumption for the positively signed $a$ priori expectation is that the fiscal policy framework implemented by the government is to optimally apply taxation revenue to fulfill the government obligations and responsibilities in the society. This should therefore contribute positively to economic growth.

\subsection{Method of Data Analysis and Decision Criterion for Validation of Hypothesis.}

The time series data would be analysed and evaluated by appropriate techniques subjecting them to preestimation, estimation and post -estimation tests. The test includes stationary test, Co-integration test, normality test,

Table 1: Descriptive statistics of log. Variables

\begin{tabular}{llllll}
\hline Statistic/Variables & LogGDP & LogCIT & LogCED & LogPPT & LogVAT \\
\hline Mean & 5.589994 & 4.588337 & 4.565628 & 5.392689 & 3.424824 \\
Mechan & 5.505921 & 4.686531 & 4.608658 & 5.656875 & 4.721428 \\
Maximum & 5.986758 & 6.917541 & 5.651806 & 7.505286 & 6.044555 \\
Minimum & 4.498944 & 2.605305 & 3.208441 & 3.573684 & 0.000000 \\
Std. Dev. & 0.311002 & 1.248010 & 0.839791 & 1.236372 & 2.592338 \\
Skewness & -0.812357 & -0.052734 & -.241150 & 0.102825 & -0.521447 \\
Kurtosis & 4.770568 & 1.817110 & 1.689443 & 1.849135 & 1.401447 \\
Jarque-Bera & 9.624339 & 2.350585 & 3.250287 & 2.277970 & 6.071632 \\
\hline
\end{tabular}

descriptive statistics test and the Ordinary Least Squares (OLS) regression analysis.

It is important to recall that time series data are prone to error due to fluctuations in activities, hence the need to subject the data to logarithm form as well as pre-estimation tests to ensure stability and normality of data for analysis.

In general, descriptive and inferential analyses which include mean (averages), maximum, standard deviation, Skewness, Kurtosis, Jarque-Bera, Probability, sum and sum-square deviations, correlation and multicolleanrity statistics, and the above stated inferential statistics would be carried out.

The decision statistics are t- values, P-values, Fvalues, $\mathrm{R}, \mathrm{R}^{2}$, adjusted $\mathrm{R}^{2}$ and Durbin-Watson statistics. The hypothesis are tested at $5 \%$ level of significance; and the null hypothesis is accepted if calculated t-value is greater than the critical or table t-value, otherwise it is rejected at n-I degrees of freedom.

\subsection{Basis of Comparative Analysis.}

The basis for comparism shall be the model summary values of the independent models, that is, model 3.1 and 3.2 which shall include R-values, $\mathrm{R}^{2}$-values, adjusted $\mathrm{R}^{2}$ value, standard error of the estimate, Durbin-Watson statistic, F-values and Case-wise diagnostics predicted values. These statistical values would shed light on which taxation revenues affect economic growth most during the period of the study.

\subsection{RESULTS AND DISCUSSION OF FINDINGS}

The results of data analyses are presented and discussed in this session of the study. The presentation is carried out systematically in the order of descriptive statistic of the Log. Variables, correlation matrix for the log. Variables, Augmented Dickey-Fuller unit root test, unrestricted co-integration rank test (trace and Eigen), pair wise Granger causality test and model estimation using regression output, and the basis of comparison between direct and indirect taxation effects on GDP using the identified statistics.

\subsection{Analysis of Descriptive Statistic for the Log Variables}

For the purpose of general analysis, the entire variables are simultaneously analyzed using the appropriate statistics. The descriptive statistics of the research variables is presented in Table 1 
"Comparative Analysis of the Effect of Direct and Indirect Taxation Revenue on Economic Growth of Nigeria"

\begin{tabular}{llllll}
\hline Probability & 0.008130 & 0.308729 & 0.196883 & 0.320144 & 0.048035 \\
Sum & 223.5998 & 183.5335 & 182.6251 & 215.7076 & 136.9930 \\
Sum Sq. Dev. & 3.772179 & 60.74366 & 27.50469 & 59.61605 & 262.0884 \\
Observations & 40 & 40 & 40 & 40 & 40
\end{tabular}

Source: Researcher's Field Data (2020)

From Table 1, mean GDP was $5.589 \%$, CIT (4.588\%), CED (4.5656\%), PPT (5.393\%), and VAT (3.425\%) respectively. Similarly, maximum and minimum values observed were GDP (5.9867\% and 4.4989\%); CIT (6.9175\% and $2.6053 \%)$; CED (5.65\% and $3.208 \%)$, PPT (7.505\% and $3.574 \%)$, VAT $(6.045 \%$ and $0.00 \%)$. The standard deviations are GDP (0.311), CIT (1.25), CED (0.839), PPT (1.236), and VAT (2.59). This values show that the period under study experienced fluctuations in respect to all variables investigated. The skewness values reflects GDP $(-0.8123)$, CIT (-0.0527), CED (-0.2412), PPT (0.1028) and VAT ($0.5214)$ respectively. These are negative indices except for PPT and show the effect that the mode, mean and median of the set of data studied all have different values. More so, the kurtosis value GDP (4.77), CIT (1.817), CED (1.689), PPT
(1.849), and VAT (1.401) respectively indicates very poor flat topped (mesokurtic) values and normality of the distribution of variables over the period of study. The JarqueBera value, which is also a test of normality of the data set, confirms the abnormality of the data set. The probability values were only statistically significant for GDP and VAT, while CIT, CED, and PPT were not statistically significant.

4.2 Analysis of Correlation Matrix for the Log. Values and Collinearity Diagnostics.

The correlation matrix gives insight into the nature of relationship subsisting among the variables of study and the collineaearity diagnostics statistics are used to measure the presence or absence of multicollinearity among the independent variables of the study. This is shown in Table 2.

Table 2: Correlation Matrix and Collinearity Statistics of the Log. Variables

\begin{tabular}{llllll}
\hline Variables & RGDP & PPT & CIT & CED & VAT \\
\hline RGDP & 1.000 & .866 & .902 & .801 & .804 \\
PPT & .866 & 1.000 & .970 & .806 & .876 \\
CIT & .902 & .970 & 1.000 & .862 & .916 \\
CED & .801 & .806 & .862 & 1.000 & .874 \\
VAT & .804 & .876 & .916 & .874 & 1.000 \\
\hline
\end{tabular}

Source: Researcher's Field Data (2020)

Table 2 established the relationship among the variables of this study. Generally, the correlation has the attribute of a rectangular or triangular display and have 1.000 value along the main diagonal. In specific expression, more perceptiveness on existing relationships is highlighted in the analysis. Coefficient of correlation in respect of RGDP is PPT (0.866), CIT (0.902), CED (0.801), and VAT (0.804) which showed pair-wise relationships. Also, the relationship among the independent variables is relatively high indicating multicollinearity. An insight into these occurrences is due to the fact that majority of companies chargeable to taxes are engaged in activities that subject them to virtually all taxes studied. The problem of multiple taxation highlighted from this outcome.

Consequent upon the high correlation values among the independent variables, collinearity diagnostics is carried out to test the variance proportions in terms of tolerance and inflation factor (VIF) as shown in Table 3.

Table 3: Collinearity Diagnostics for the Log. Variables

\begin{tabular}{|c|c|c|c|c|c|c|c|c|}
\hline \multirow[b]{2}{*}{$\begin{array}{l}\text { Model } \\
\text { Dimension }\end{array}$} & \multirow[b]{2}{*}{$\begin{array}{l}\text { Eigen } \\
\text { value }\end{array}$} & \multirow[b]{2}{*}{$\begin{array}{l}\text { Condition } \\
\text { index }\end{array}$} & \multicolumn{6}{|c|}{ Variance Proportion } \\
\hline & & & (Constant) & $\begin{array}{l}\text { Log } \\
\text { PPT }\end{array}$ & $\begin{array}{l}\text { Log } \\
\text { CIT }\end{array}$ & $\begin{array}{l}\text { Log } \\
\text { CED }\end{array}$ & $\begin{array}{l}\text { Log } \\
\text { VAT }\end{array}$ & Tolerance \\
\hline 1 & 4.764 & 1.000 & .00 & .00 & .00 & .00 & .00 & - \\
\hline 2 & .219 & 4.669 & .01 & .00 & .00 & .00 & .15 & .56 \\
\hline 3 & .011 & 20.478 & .11 & .08 & .05 & .12 & .28 & .036 \\
\hline 4 & .005 & 32.101 & .72 & .01 & .02 & .72 & .55 & .203 \\
\hline 5 & .001 & 59.987 & .16 & .91 & .93 & .15 & .02 & .133 \\
\hline
\end{tabular}

Source: Researcher's Field Data (2020).

From Table 3, the result of collinearity diagnostics shows that the variance proportions and tolerance were all less than 10, implying that after subjecting the data set to this diagnostics, there is no further evidence of multicollinearity, 
hence, other analyses such as unit root and co-integration can be conducted.

\subsection{Analysis of Integration Properties}

The first step involved in the estimation of a linear relationship is the comprehensive pre-testing procedure to investigate the characteristics of the time series variables. This is carried out using the Augmented Dickey Fuller-Unit Root test and co-integrated rank test (Trace and Eigen).

Table 4. Augmented Dickey Fuller-Unit Root Test

\begin{tabular}{|c|c|c|c|c|c|}
\hline \multirow[t]{2}{*}{ Variables } & \multicolumn{2}{|c|}{ ADF Statistics computed } & \multicolumn{2}{|c|}{$5 \%$ critical Level } & \multirow[t]{2}{*}{ Remarks } \\
\hline & Level & $1^{\text {st }}$ Difference & Level & 1st Difference & \\
\hline Log CED & -2.973487 & -3.529758 & -3.529758 & -2.767275 & $1(1)$ \\
\hline Log CIT & -1.839024 & -3.529758 & -3.529758 & -2.767275 & $1(1)$ \\
\hline Log PPT & -2.767275 & -3.529758 & -3.529758 & -2.767275 & $1(1)$ \\
\hline Log VAT & -1.640165 & -3.529758 & -3.529758 & -2.767275 & $1(1)$ \\
\hline Log RGDP & -2.031233 & -3.533083 & -3.533083 & -2.031233 & $1(1)$ \\
\hline
\end{tabular}

Source: Researcher's Field Data (2020).

The Table 4 is the Augmented Dickey Fuller-Unit root test on variables. The test result indicates non-stationarity nature of the studied variables at level but the variables integrate at order one 1(1). Therefore, the existence of long run relationship among variables is examined with the Johansen Co-Integration test. In making reference, Trace Test Statistics and maximum Eigen value criteria are applied. The decision criteria was that when the Trace Statistics is greater than the $5 \%$ critical value, hypothesis of no co-integrating relationship among the variables is rejected and concluded that there is cointegrating relationship among them. The co-integration test results presented in Table 4 are carried out in a systematic manner. Tests are run for variable constituting the regression equation before the equation is estimated.

Table 6: Unrestricted Co-integration Rank Test (Trace and Eigen)

\begin{tabular}{lllll}
\hline $\begin{array}{l}\text { Hypothesized No. of } \\
\text { CE(s) }\end{array}$ & Eigen value & Max-Eigen Statistic & Trace Statistic & 0.05 critical value \\
\hline None & & & \\
At most 1 & 0.559568 & 31.15999 & 64.90930 & $33.87687^{*}$ \\
At most 2 & 0.380394 & 18.18952 & 33.74931 & $27.58434^{*}$ \\
At most 3 & 0.182895 & 7.675550 & 15.55979 & $21.13162^{*}$ \\
At most 4 & 0.135886 & 5.549940 & 7.884245 & $14.26560^{*}$ \\
\hline
\end{tabular}

Trace test and max-eigen value test indicates no co-integration at the 0.05 level *denotes rejection of the hypothesis at the 0.05 level.

Source: Researcher's Field Data (2020)

\subsection{Pair-wise Granger Causality Test}

The pair-wise Granger Causality test is employed to test for causality direction between direct and indirect taxation revenue and economic growth in Nigeria. The result of the test is presented on Table 5

Table 5: Pair-wise Granger Causality Test

\begin{tabular}{lllc}
\hline Null Hypothesis & Obs. & F-statistic & Probability \\
Log RGDP does not Granger cause Log CED & 38 & 0.96795 & 0.3904 \\
Log CED does not Granger cause Log RGDP & & 0.89720 & 0.4174 \\
Log RGDP does not Granger cause Log CIT & 38 & 0.23535 & 0.7916 \\
Log CIT does not Granger cause Log RGDP & & 1.73648 & 0.1918 \\
Log RGDP does not Granger cause Log PPT & 38 & 1.12261 & 0.3375 \\
Log PPT does not Granger cause Log RGDP & & 1.66399 & 0.2049 \\
Log RGDP does not Granger cause Log VAT & 38 & 0.34690 & 0.7094 \\
Log VAT does not Granger cause Log RGDP & & 3.02722 & 0.0621 \\
\hline
\end{tabular}

Source: Researcher's Field Data (2020) 
The results of the Granger Causality test in Table 5 revealed the pair-wise causality test between the variables of study. The result indicates that the hypothesis that direct and indirect taxation revenue does not cause economic growth and vice versa present brick picture that there is no unidirectional or bidirectional running in either direction of dependent and independent variables for this study. This is because the probability values are all statistically at variance with 0.05 level of significance.

\subsection{Model Evaluation, Test of Hypotheses and Findings}

The evaluation of model and test of hypotheses is carried out using the ordinary least square (OLS) results of the regression analysis. Thus, the model evaluation is done systematically on hypothesis by hypothesis basis.

\subsubsection{Test of Hypothesis one}

Hypothesis one of the study was stated in it null form as "There is no significant effect of direct taxation revenue on economic growth in Nigeria". To test this hypothesis, we restated model 3.1c which reflects the Logarithmic form of the variables.

$\log \mathrm{RGDP}=\mathrm{a}_{0}+\log _{\mathrm{a} 1} \mathrm{PPT}+\log _{\mathrm{a} 2} \mathrm{CIT}+\mu$

$\log \mathrm{RGDP}=4.592110-0.033590+0.256961+0.137681$

Std. Error $=0.110487 \quad 0.072951 \quad 0.042271$

$\mathrm{t}$ - stat $=\quad 41.56227 \quad-0.491442 \quad 3.555524$

prob. $=\quad \begin{array}{lll}0.0000 & 0.6479 & 0.0011\end{array}$

$\mathrm{R}^{2}=0.814066(81.41 \%)$

Adj. $R^{2}=0.804015(80.40 \%)$

F-stat $=80.99763$

Prob $($ F-statistic $)=0.00000$
Durbin-Watson stat $=1.213757$

F-tab $=$ Critical value of F-statistic at $5 \%$ level of significance 2.61

The result indicates that real gross domestic product (RGDP) will increase by 4.59211 units if all the independent variables are held constant. The independent variables in this model are direct taxation components of Petroleum Profit Tax (PPT) and Company Income Tax (CIT). On the other hand, a unit increase in PPT variables will lead to decrease of 0.033590 units in RGDP; a unit increase in CIT variables will lead to an increase of 0.25691 unit in RGDP and stochastic error of 0.137681 for variables not captured in the model.

In terms of the degree of relationship between the dependent and independent variables, the coefficient of determination $\left(\mathrm{R}^{2}\right)$ value of $0.814066(81.41 \%)$ indicates a strong positive correlation between direct taxation and economic growth in Nigeria. The adjusted $\mathrm{R}^{2}$ value of $0.814066(80.40 \%)$ reveals that the variations in RGDP within the period of study is accounted for by variables with the remaining $19.6 \%$ of the variation accounted for by variables not captured but represented by the stochastic error term. The Durbin-Waston statistic value of 1.2 is within the range of between 1 and 3 , and thus explains that there is no autocorrelation and results are not spurious and good for policy formation.

In the determination of the statistical significance of the independent variables, the computed t-statistics values of the independent variables are compared to the tabulated or critical t-value at $5 \%$ level of significance and n-1 degrees of freedom. The result is presented on Table 7.

Table 7: Statistical significance of Independent variables for Hypothesis one.

\begin{tabular}{|c|c|c|c|c|}
\hline Variables & Computed t-value & $\begin{array}{l}\text { Critical t-value (@ } \\
5 \% \text { level) }\end{array}$ & Probability & Decision \\
\hline LogPPT & -0.460442 & 1.645 & 0.6479 & Not significant \\
\hline LogCIT & 3.555524 & 1.645 & 0.011 & Significant \\
\hline
\end{tabular}

Source: Researcher's Field Data (2020)

Table 7 shows that Petroleum Profit Tax (PPT) is not statistically significant, while Companies Income Tax (CIT) is statistically significant, in relation to RDGP. This is because, in the case of PPT, the critical t-value is greater than the computed, and for the CIT the reverse is the case. This also applies to the p-value which for PPT $(0.6479>0.05)$ and for CIT $(\mathrm{P}=0.01<0.05)$.

Finally, the computed F-statistic value of 80.997 indicates that the model for the hypothesis is a good fit to explain the changes in Gross Domestic product in Nigeria during the period of the study. Thus, as the 80.997 value is greater than the critical F-value of 2.61, and the probability of F-statistics is less than 0.05 , the null hypothesis is rejected, and the alternative accepted that there is a significant effect of direct taxation revenue on economic growth in Nigeria".
The results is at variance with those of llaboya and Mabame (2012); Worlu and Nkoro (2012); and Ifurueze and Ekezie (2014) who disclosed negative effects, but affirms the findings of Etim, Umoffong and Confidence (2020), Etim, Nweze and Umoffong (2020) who found positive relationship between direct taxes component and economic growth in Nigeria.

\subsubsection{Test of Hypothesis Two}

The second hypothesis stated that "indirect taxation revenue has no significant effect on economic growth of Nigerian between 1980 and 2019". To test this hypothesis, the logarithmic model of model 3.2 is used, which was stated as:

$\operatorname{LogRGDP}=\mathrm{b}_{0}+\log _{\beta 1} \mathrm{VAT}+\operatorname{LogCED}+\mathrm{e}$

$\operatorname{LogRGDP}=(4.707814)(0.053047) \quad(0.153430)(0.178492)$ 
Std. Error $=(0.256516)(0.070127) \quad(0.022718)$

$\mathrm{t}$-stat. $\left.=\begin{array}{lll}(18.35291) & (2.187882) & (2.335054\end{array}\right)$

Prob. $=\left(\begin{array}{lll}(0.0000) & (0.0351) & (0.0251)\end{array}\right.$

$\mathrm{R}^{2}=0.687503(68.75 \%)$

Adj. $R^{2}=0.670612$

F-stat. $=40.70065$

Prob. (F-stat. $)=0.0000$

Durbin-Watson stat. $=0.68$

F-tab $=$ critical value of F-statistics at $5 \%$ level of significance $=2.61$

The result indicates that Gross Domestic Product (GDP) in Nigeria will increase by 4.707814 units if all the independent variable are held constant. The independent variables in this study were indirect taxation: Value Added Tax (VAT) and Custom and Excise Duties (CED). On the other hand, an increase in Value Added Tax variables will lead to an increase of 0.053047 units in GDP as well as 0.153430 units as a result of CED variables increase. The stochastic error term of 0.178492 represent variables not captured in the model of this study.

In examining the degree of relationship between the dependent and independent variables, the coefficient of determination $R^{2}$ and adjusted $R^{2}$ values of 0.6875 (68.75\%) and $0.6706(67.06 \%)$ respectively are used. This reveals that about $69 \%$ or $67 \%$ variation in gross domestic product is accounted for by the variables of the model with about $31 \%$ or $33 \%$ accounted for by those variables not captured in the model but represented by the error term. The Durbin-Watson statistic value of 0.68 is approximately within the range of 1 and 3, and thus explains that there is no auto-correlation and results are not spurious and good for policy formulation.

In the determination of statistical significance, of the independent variables, the computed t- statistic values of the independent variables are compared with the critical or tabulated values at $\mathrm{n}-1$ degrees of freedom and 5\% significance level. The results are shown in Table 8.

Table 8. Statistical Significance of Independent Variables for Hypothesis Two

\begin{tabular}{|c|c|c|c|c|c|}
\hline Variables & $\begin{array}{l}\text { Computed } \\
\text { value }\end{array}$ & t- & $\begin{array}{l}\text { Critical t-value } \\
\text { (@ 5\% level) }\end{array}$ & Probability & Decision \\
\hline LogCED & 2.18782 & & 1.645 & 0.0351 & Significant \\
\hline LogVAT & 2.335054 & & 1.645 & 0.0251 & Significant \\
\hline
\end{tabular}

Source: Researcher's Field Data (2020)

Table 8 shows that the CED and VAT have statistically significant relationship with gross domestic product in Nigeria during the period of the study. This is because the respective computed $t$-values are greater than the critical $t$ value statistic. Also, the respective probabilities of the $t-$ statistic value are within the acceptable 5\% region.

More so, the computed F-statistic value of 40.70 indicates that the model for the hypothesis is a good fit to explain the changes in gross domestic product, as the value is greater than the critical F-statistic of 2.61 and the probability of the F-statistic of 0.00000 is less than 0.05 , the null hypothesis is hereby rejected. This is in conformity with the findings of Okonkwo and Chukwu (2019); Eze and Celina (2018); Etim, et al., (2020) who also found positive and significant relationship between these taxation revenue components and economic growth in Nigeria.

\subsubsection{Test of Hypothesis three}

The test of hypothesis three is the bane of this research study and form the basis of comparison of the effects of direct and indirect taxation revenue on economic growth of Nigeria as well as the discussion of findings.

\section{Basis of Comparison and Discussion of the Findings}

The main objective of this study was to conduct a comparative analysis of the effect of direct and indirect taxation revenue on economic growth of Nigeria. To carry out the comparative analysis, the $\mathrm{R}^{2}$, adjusted $\mathrm{R}^{2}$, F-cal. Statistic, Prob. (F.stat), Standard Error values of models 1 and 2 were used. Most importantly, the case-wise residuals statistics comparing of maximum, minimum, mean and standard deviations are used to draw inference. The statistics are presented in Table 9

Table 9. Basis of comparative Analysis of Effect of Direct and Indirect Taxation Revenue on Economic Growth of Nigeria

\begin{tabular}{llll}
\hline Statistics & Direct Taxation & Difference & Indirect Taxation \\
\hline $\begin{array}{l}\text { Casewise Residual statistics (predicted } \\
\text { value) }\end{array}$ & & & \\
Mean & 5.589994 & - & 5.589994 \\
Maximum & 6.123317 & 0.229687 & 5.893630 \\
Minimum & 5.133892 & -0.066192 & 5.200084 \\
Standard Deviation & .2806038 & 0.227335 & .2578703 \\
$\mathrm{R}^{2}$ & $0.81(81 \%)$ & $12.3 \%$ & $0.687(68.7 \%)$ \\
Adjusted $\mathrm{R}^{2}$ & $0.80(80 \%)$ & $13 \%$ & $0.670(67)$
\end{tabular}


"Comparative Analysis of the Effect of Direct and Indirect Taxation Revenue on Economic Growth of Nigeria"

$\begin{array}{llll}\text { F-cal. Statistics } & 80.99 & 40.29 & 40.70 \\ \text { Prob. (F-cal statistics) } & 0.0000 & - & 0.000 \\ \text { Standard error } & 0.137681 & -0.040811 & 0.178492 \\ \text { Durbin-Watson statistic } & 1.2137 & 0.53253 & 0.68117\end{array}$

Source: Researcher's Field Data (2020).

From Table 9, the basis of our comparative analysis is the difference between the direct and indirect taxation revenue values as disclosed from the case-wise residual statistics (predicted values) and regression residual statistics as shown under the difference column on the table.

The mean values for both direct and indirect taxation revenues effect is the same. This implies that on average, the two taxation sources have equal average effect on the economy. On the predicted maximum value; direct taxation revenue has a higher differential effect of 0.229687 above indirect taxation revenue on the economy as well as the standard deviation value of 0.227335 , while the minimum predicted value was -0.066192 in favour of direct taxation revenue.

Also, using the regression residual statistics, the coefficient of determinant $\left(\mathrm{R}^{2}\right)$ show $12.3 \%$ higher value between direct taxation revenue and indirect taxation revenue. This also relate to adjusted $\mathrm{R}^{2}$ with a differential value of $13 \%$ between the two components; The F-calculated statistics is 40.29 different, balanced Prob (F-cal. statistics) of 0.0000 , standard error value of -0.040811 in favour of indirect taxation as well as the Durbin-Watson statistic value of 0.53253 differentials.

From the above comparative analysis, the theoretical postulation that direct taxation impact negatively on economic growth is upheld giving the higher predictive casewise values, while indirect taxation encourages economic growth since tax incidence and burden can be shifted for the initial payer to the final consumer.

\subsection{SUMMARY, RECOMMENDATIONS} CONCLUSION

AND

The study was set out to comparatively analyse the effect of direct and indirect taxation revenue on economic growth of Nigeria. The study involves unit root analysis, cointegration test, pair-wise granger casualty tests, ordinary least squares, and case-wise diagnostics analyses. Three hypotheses were developed in the study and tested using results of the descriptive and inferential statistics. Two types of taxes each were used for each class of taxes, Petroleum Profit Tax (PPT), Companies Income Tax (CIT) for direct taxation and Value Added Tax (VAT) and Custom and Excise Duties (CED) for indirect taxation and Real Gross Domestic Product (RGDP) proxy for economic growth. The study covers a period of forty (40) years form 1980- 2019, with data obtained from the Central Bank of Nigeria (CBN), and Federal Inland Revenue Service (FIRS) for various years.

\section{$5.1 \quad$ Conclusion}

From the findings of the study, the conclusions drawn are:

i. Petroleum Profit Tax (PPT) has a negative coefficient on economic growth with values not statistically significant.

ii. Companies Income Tax (CIT) has positive coefficient which are statistically significant.

iii. Aggregative, direct taxation has effect on economic growth.

iv. Value Added Tax (VAT) has positive coefficient that is statistically significant.

v. Custom and Excise Duties (CED) has positive coefficient that is statistically significant.

vi. Aggregatively, indirect taxation had effect on economic growth.

vii. Using case-wise predictive residual statistics, direct taxation has more negative effect than indirect taxation on economic growth.

\subsection{Recommendations}

From the above findings, the following recommendations are proffered.

i. With PPT having negative coefficient on economic growth, the government should as a matter of urgency review operational policies at the petroleum sector so as to boost activities and investments that might turn the fortunes at the sector.

ii. Companies Income Tax reforms in the form of reliefs and other incentives should be enhanced in the country.

iii. As is already done, VAT rate should be increased with relevant structure to encourage productive activities so as to enhance more VAT revenue.

iv. Custom and Excise Duties (CED) should he reviewed such as reduction of import duties to minimum in formal sector activities and encourage exportation and importation out and into the country.

\subsection{Policy implication of the findings}

From the empirical analysis and the result of the findings the policy direction is created for the government as part of the fiscal policy framework. Government should refine the policy framework in the petroleum (oil and gas) sector to stimulate activities at the sector. Also, more incentives and tax reliefs as it has to do with company taxation should be address such as capital allowances, investment allowance, and reliefs for investors in some preferred sector particularly the solid mineral sector which as lie dormant since independence. 


\section{4}

\section{Contribution to knowledge}

This study has added to existing literature in accounting, economics, finance and taxation by way of empirical analysis carried out on the basis of comparative evaluation of the effect of direct and indirect taxation revenue on economic growth. Also, the stylize approach of using casewise residual statistics (predictive values) to compare the effect of direct and indirect taxation on economic growth of Nigeria is one of its kind, which stands the study out among earlier researches in the area of interest.

\section{REFERENCES}

1. Abata, M. A. (2014). The Impact of tax revenue on Nigerian economy (case of Federal Board of Inland Revenue). Journal of policy and Development Studies 9(1):109-121

2. Abiola, O. A and Asiweh, N. (2012). Impact of tax reform and economic growth of Nigeria: A time series analysis. Current Research Journal of Social Sciences, 4(1):62-68

3. Abomaye-Nimenibo, W. A, Eyo, M. J and Friday, H. C (2018). An empirical analysis of tax revenue and economic growth in Nigeria from 19802015.Global Journal of Human-social Science, 18(3):8-39

4. Adam Smith (1776). The Wealth of Nations. London, Everyman's Library Ltd, 718p

5. Aderteti, S. A., Adesina, J. A and Sanni, M. R. (2011). Value added tax and economic growth of Nigeria. European Journal of Humanities and Social Sciences, 10(1):455-471

6. Afuberoh, D. and Okoye, E. (2014). The impact of taxation on revenue generation in Nigeria: A study of Federal Capital Territory and selected States. International Journal of Public Administration and Management research, 2(2):22-47

7. Bhartia, H. L (2009). Public finance ( $13^{\text {th }}$ Edition). New Dehli: Vikas Publishing House PVT Ltd, 718p

8. Bruno, O. O and Emmanuel, A. O. (2019). Tax revenue and the Nigerian Economy International Journal of Academic Science Research (IJAMSR) 3(2):61-66

9. Chigbu, E. E and Njoku, C. C (2015). Taxation and the Nigerian Economy (1994-2012). Management Studies and Economic systems Journal (MSESJ), 2(2):111-128

10. Chigbu, E. E., Akujuobi, L. E and Appah, E (2012). An empirical study on the causality between economic growth and taxation in Nigeria. Current Research Journal of economic Theory, 4(2):29-38

11. Companies Income Tax Act (2004). Federal Inland Revenue Services (FIRS), Abuja, Nigeria; 21-33

12. Customs, Excise and Tariffs (2004). National Development Act; Federal Government of Nigeria, Abuja; 41-52
13. Dang, D. Y. and Bala, A. (2018). Contribution of tax revenue for National development in Nigeria. IJMSR, 1(1):208-2018

14. Domar, E. (1957). Essays in the theory of Economic growth. New York Oxford University press, 523p

15. Dwivedi, D. N. (2004). Managerial Economics, $\left(6^{\text {th }}\right.$ Edition) London: Matins press Inc. $421 \mathrm{p}$

16. Engen, E. and Skinner, J. (2008). Taxation and economic growth. National Tax Journal, 49(4):617642

17. Eric, E. and Jonathan, S. (1996). Taxation and Economic growth. National Tax Journal, 49(4):617642

18. Etim E. O (2015) Tax revenue and economic growth in Nigeria from 1980-2013.Unpublished PhD. Thesis. Postgraduate school, University of Uyo, Nigeria, $157 \mathrm{~d}$

19. Etim E. O and Nweze, A. U (2020). Tax revenue components and economic growth in Nigerian from 1980-2013. $I^{\text {st }}$ ICAN Academic Conference on Accounting and financial proceedings: 1135-1148

20. Etim, E. O, Mbobo E. M, Confidence, I. J., and Ekanem D. J (2020). Taxation and manufacturing sector output in Nigeria. International Journal of Research and innovation in Social science (IJRISS), iv (vii):240-249

21. Etim, E. O, Nweze, A. U, Umoffong, N. J and Elias I. A (2020). Empirical analysis of the relationship between tax revenue components and economic growth in Nigeria. Journal of Accounting and Financial Management, 6(3):1-18

22. Etim, E. O, Umoffong, N. J and Ekanem, D. J. (2020). Does taxation drive economic development in Nigeria? International Journal of Research and Scientific Innovation (IJRSI), vii (vi)

23. Etim, E. O., Umoffong, N. J. and Confidence, I. J. (2020). Does taxation propel economic growth in Nigeria? International Journal of Research and Innovation in Social Science (IJRISS), iv(vi)

24. Eze, O. M. and Celina, U. C. (2018). Re-evaluation of the economic impact of tax policy on the growth of Nigerian Economy. IOSR Journal of Economics and Finance (IOSR-JEF), 9(2):61- 73

25. Fadare, S. O. (2010). Recent Baking Reforms and Economic growth in Nigeria. Middle Eastern Finance and Economics, 8:1450-1468.

26. Ifurueze, M. S and Ekezie, C. A. (2014). The Nigerian tax system and Economic growth: A time series analysis. International Journal of Economics and Empirical Research, 2(4):163-169

27. Ilaboya, J and Mgbame, C. (2013). Direct tax and economic growth in Nigeria. ICAN Journal of Accounting and Finance, 2(1):65-81. 
28. Jhingan, M. (2004). Money, banking, International trade and public finance ( $7^{\text {th }}$ Edition) New Delhi: Vrinda publication Ltd, 1120p

29. Khorravi, A. and Karimi, M. S. (2010). To investigate the relationship between monetary policy, fiscal policy and economic growth in Iran: Auto-regression Distributed log Approach to Cointegration. American Journal of Applied Sciences, 7(3):420-424

30. Konrad, K. A (2014). Taxes on risky returns. Canadian Journal of Taxation, 14(3):718-74

31. Lyndon, M. E and Paymaster, F. B (2016). Tax revenue and Nigerian economy growth. Research Journal of Finance and Accounting, 7(12):34-51

32. Musgrave, R. ad Musgrave, P. (2004). Public finance in theory and Practice, (5 $5^{\text {th }}$ edition). New Delhi-India: Tata McGraw Hill Education Ltd, 805p

33. Nwezeaku, N. C. (2015). Taxation challenges and revenue generation in Nigeria. International Journal of Accounting, Taxation and Management, 6(2):114-128

34. Nzotta, S. (2007). Tax evasion and avoidance problems in Nigeria: A critique. The Nigerian Accountant, 40(2):40-45

35. Okafor, R. (2012). Tax revenue generation and Nigerian Economic development. European Journal of Business and Management, 4(19):50-65

36. Okonkwo, I. V and Chukwu, K. O (2019). Government tax revenue and economic development in Nigeria: 1996-2017. International Journal of Research in Business, Economics and Management, 3(3):91-105

37. Okonkwo, J. J and Chukwu, B. A (2019). Infrastructural development and Industrial sector productivity in Sub-saharan Africa. Journal of Economics and Development, 22(1):91-109

38. Olapade, B. C and Olapde, D. O. (2010). The impact of government spending on economic growth and development in Nigeria. Journal of Economics and Finance Research, 12(1):114-127

39. Omitogun, O. and Ayinola, T. (2007). Fiscal policy and Nigerian economic growth. Journal of Research in Nigerian Development, 5(2):112-128.

40. Onaolapo, A. A., Aworemi, A. T. and Ajala, F. T. (2013). The analysis of the effect of petroleum profit tax on Nigerian economy. Asian Journal of Humanities and Social Sciences, 4(7):1-12

41. Osiegbu, P. I., Onuorah, A. C and Nnamdi, I. (2010). Public finance: Theories and practice. C. M. Global Co. Ltd. Cable point Asaba, 364p Propel economic growth in Nigeria? International Journal of Research and Innovation in Social Science (IJRISS), iv (vi)
42. Solow, R. (1956). A contribution to the theory of economic growth. The Quarterly Journal of Economics, 70(1):65-94

43. Udofot, P. O and Etim, E. O (2017). The effect of tax revenue components from SME's and Economic growth of Nigeria. Available @ https://www.semantic scholar. org > paper. Accessed 20/08/2020

44. Worlu, C. N and Nkoro, E. (2012). Tax revenue and economic development in Nigeria: A macroeconometric approach. Academic Journal of Interdisciplinary Studies, 1(2):211-223 